\title{
PENGARUH MODEL QUANTUM TEACHING TERHADAP KEMAMPUAN BERPIKIR KRITIS PESERTA DIDIK PADA PEMBELAJARAN MATEMATIKA KELAS V SDN
}

\author{
ALBEN AMBARITA ${ }^{1}$, PUTRI INTAN NUR JANAH ${ }^{2}$, HERMAN TARIGAN ${ }^{3}$ \\ (UNIVERSITAS LAMPUNG ${ }^{1,2,3}$ )
}

\begin{abstract}
The purpose of this research is to determine the significant influence and differences on the application of the quantum teaching models to the critical thinking skills. This type of research is quasi experimental research. The design used is non-equivalent control group design. The study population was 52 students and use the sample was saturated.. Data analysis techniques using a simple regression test and t-test sparated varians. The results showed there was a significant influence on the aplication of quantum teaching models on critical thinking skills with $F_{\text {count }}>F_{\text {table }}$ and $t_{\text {count }}>t_{\text {table }}$ and there was an increase in student's critical thinking skills which the criteria of "Medium".
\end{abstract}

Keywords: critical thinking skills, mathematics, quantum teaching

\section{PENDAHULUAN}

Pendidikan merupakan salah satu faktor yang dianggap berperan dalam kemajuan suatu bangsa. Semakin baik kualitas pendidikan maka semakin baik kualitas sumber daya manusia (SDM), dengan begitu maka suatu bangsa juga akan meningkat kualitasnya karena dibangun oleh manusia-manusia yang memiliki ide-ide cemerlang.

Pendidikan dasar merupakan jenjang pendidikan paling awal yang memiliki peran penting untuk menumbuhkan pengetahuan peserta didik.. Pendidikan akan terlaksana dengan baik apabila dalam pelaksanaannya terdapat rencana dan pedoman yang jelas. Pedoman yang diperlukan dalam pelaksanaan pendidikan adalah kurikulum. Azizah dkk (2018: 63) mengemukakan bahwa tujuan diberlakukannya Kurikulum 2013 di Indonesia diantaranya adalah mengembangkan keterampilan berpikir tingkat tinggi Higher Order Thinking 
Skills (HOTS), salah satu keterampilan berpikir tingkat tinggi adalah kemampuan berpikir kritis.

Shanti (2017: 52) menyatakan kemampuan berpikir kritis merupakan kemampuan berpikir tingkat tinggi yang terdiri dari elemen penting seperti menginterpretasi, menganalisis, mengevaluasi, serta membuat suatu keputusan untuk memecahkan masalah. Lai (dalam Rosyida, 2016: 209) juga berpendapat bahwa kemampuan berpikir kritis adalah kemampuan peserta didik dalam menganalisis argumen, membuat kesimpulan menggunakan penalaran, menilai atau mengevaluasi, dan membuat keputusan atau pemecahan masalah.

Peneliti menyimpulkan bahwa kemampuan berpikir kritis adalah kemampuan seseorang dalam berpikir lebih mendalam dengan cara menganalisis dan mengevaluasi suatu informasi yang diperoleh melalui pengalaman, pengamatan, observasi dan kegiatan-kegiatan lain sehingga mampu membuat keputusan atau tindakan yang baik dalam menyelesaikan suatu permasalahan. Penelitian ini menggunakan indikator kemampuan berpikir kritis yaitu interpretasi (memahami dan mengungkapkan makna), analisis (mengidentifikasi hubungan aktual), evaluasi (menilai kredibilitas pernyataan atau kekuatan logis dari hubungan inferensial), inferensi (mengidentifikasi unsur-unsur untuk menarik kesimpulan) karena lebih cocok digunakan untuk mata pelajaran matematika dan sesuai dengan tingkat perkembangan kognitif peserta didik usia sekolah dasar (tahap operasional konkret).

Kemampuan berpikir kritis dapat dikembangkan melalui kegiatan pembelajaran yang mendorong peserta didik untuk aktif dalam mencari, menjelaskan informasi dari berbagai sumber dan mencari solusi, serta menilai dan 
bertanggungjawab atas segala tindakan yang dilakukan. Model quantum teaching dapat menjadi salah satu alternatif yang dapat digunakan. Sebagaimana pernyataan Poter (2014: 47) bahwa model quantum teaching memiliki kelebihan yaitu memberikan kebebasan belajar, menjadikan peserta didik lebih aktif dan berani mengungkapkan pendapat atau ide, pemahan peserta didik terhadap materi cukup tinggi, dan menciptakan keriangan dan ketakjuban dalam belajar. Selain itu Supramono (2016: 80) juga berpendapat bahwa quantum teaching adalah salah satu model pembelajaran yang melibatkan seluruh aspek-aspek yang mendukung pencapaian tujuan pembelajaran sehingga proses pembelajaran menjadi lebih menyenangkan dan bermakna bagi pendidik dan peserta didik.

Peneliti dapat menyimpulkan bahwa model pembelajaran quantum teaching adalah suatu pembelajaran dengan menjadikan pembelajaran lebih bermakna melalui interaksi yang berlangsung secara dinamis guna mengoptimalkan pencapaian prestasi belajar yang tinggi, memberdayakan seluruh potensi yang ada sehingga tercipta suasana belajar nyaman dan menyenangkan. Pembelajaran yang dilakukan dapat memfasilitasi peserta didik untuk menemukan konsep sendiri melalui pengalamannya yang bermakna.

Hasil observasi dan wawancara yang dilakukan terhadap wali kelas V SDN 1 Metro Timur pada tanggal 24 Oktober 2019 menunjukkan bahwa hasil belajar peserta didik yang rendah diakibatkan rendahnya kemampuan berpikir kritis peserta didik. Hal tersebut disebabkan karena penerapan model pembelajaran cenderung berpusat pada pendidik (teacher centered) sehingga peserta didik lebih cenderung mendengarkan pendidik daripada bertanya dan menganalisis dalam proses pembelajaran. Selama proses pembelajaran berlangsung, pendidik hanya 
menjelaskan materi sementara peserta didik hanya mendengarkan penjelasan dari pendidik. Proses pembelajaran tersebut menyebabkan peserta didik kurang aktif sehingga kemampuan berpikir kritis peserta didik kurang berkembang.

Tabel 1. Data nilai mid semester ganjil kelas V SDN 1 Metro Timur tahun pelajaran 2019/2020

\begin{tabular}{|c|c|c|c|c|c|c|c|c|}
\hline & & & & & Jumlah & $\begin{array}{c}\text { Jumlah } \\
\text { peserta }\end{array}$ & \multicolumn{2}{|c|}{ Persentase (\%) } \\
\cline { 7 - 10 } No. & Kelas & $\begin{array}{c}\text { Jumlah } \\
\text { peserta } \\
\text { didik }\end{array}$ & KKM & $\begin{array}{c}\text { Rata-rata } \\
\text { nilai } \\
\text { kelas }\end{array}$ & $\begin{array}{c}\text { peserta } \\
\text { didik } \\
\text { tuntas }\end{array}$ & $\begin{array}{c}\text { didik } \\
\text { belum } \\
\text { tuntas }\end{array}$ & $\begin{array}{c}\text { Tuntas } \\
(\%)\end{array}$ & $\begin{array}{c}\text { Belum } \\
\text { Tuntas } \\
(\%)\end{array}$ \\
\hline 1. & VA & 26 & 75 & 73.7 & 7 & 19 & 27 & 73 \\
\hline 2. & V B & 26 & 75 & 57,6 & 3 & 23 & 11 & 89 \\
\hline
\end{tabular}

Sumber: Dokumentasi pendidik kelas V SDN 1 Metro Timur

Berdasarkan tabel 1, dapat dilihat bahwa nilai peserta didik kelas V SDN 1 Metro Timur masih rendah karena belum mencapai Kriteria Ketuntasan Minimum (KKM) yang telah ditentukan yaitu 75 . Rata-rata nilai kelas V A sebesar 73,7 dengan persentase yang tuntas $27 \%$, sedangkan rata-rata nilai kelas V B sebesar 57,6 dengan persentase yang tuntas hanya sebesar $11 \%$. Oleh sebab itu, peneliti memilih kelas V B sebagai kelompok eksperimen karena nilai rata-rata dan persentase yang tuntas di kelas V B lebih rendah dari kelas V A, adapun kelas V A sebagai kelompok kontrol.

Fakta yang terjadi berdasarkan beberapa penelitian diperoleh informasi bahwa sebagian besar peserta didik mengalami masalah dalam hal rendahnya kemampuan berpikir kritis. Diantaranya yaitu Mullis (dalam Azizah, 2018: 62) menyatakan dalam Program for International Student Assessment (PISA), 
Indonesia berada di peringkat 60 dari total 65 negara peserta. Data ini menunjukkan bahwa kemampuan peserta didik sekolah dasar di Indonesia berada di bawah rata-rata. Sejalan dengan hal tersebut, studi yang dilakukan oleh Trends in International Mathematics and Science Study (TIMSS) tahun 2015 yang diikuti oleh peserta didik sekolah dasar, Indonesia memperoleh hasil belajar dan kemampuan berpikir kritis dalam kategori rendah pada bidang matematika yaitu peringkat 45 dari 50 negara dengan skor 397 . Hal tersebut terjadi disebabkan kebanyakan peserta didik terbiasa melakukan kegiatan belajar berupa menghafal konsep, rumus, dan menyelesaikan soal-soal secara matematis, tanpa pengembangan kemampuan berpikir kritis terhadap suatu masalah yang mereka hadapi dalam kehidupan nyata.

Cara mengajar yang masih konvensional berpengaruh pada kemampuan berpikir kritis dan hasil belajar peserta didik. Akibatnya, kemampuan kognitif tingkat tinggi peserta didik sangat lemah karena kegiatan pembelajaran yang biasa dilakukan hanya mendorong peserta didik pada proses menghafal daripada memahami konsep sehingga kemampuan berpikir peserta didik seperti kemampuan berpikir kritis menjadi kurang berkembang.

Model quantum teaching dapat menjadi salah satu alternatif yang dapat digunakan. Peneliti menggunakan langkah-langkah model quantum teaching yang dikemukakan oleh Wena (2014: 165-166) dengan istilah "TANDUR" yaitu Tumbuhkan, Alami, Namai, Demonstrasikan, Ulangi, dan Rayakan karena dijelaskan secara rinci pada tahapan-tahapan serta kegiatan-kegiatan yang dilaksanakan dalam mengimplementasikan model quantum teaching yang peneliti 
rasa tepat untuk diterapkan pada pembelajaran matematika untuk peserta didik tingkat sekolah dasar.

Berdasarkan hal tersebut, penelitian ini dilakukan dengan tujuan penelitian yaitu sebagai berikut.

1. Untuk mengetahui adanya pengaruh yang signifikan pada penerapan model quantum teaching terhadap kemampuan berpikir kritis peserta didik pada pembelajaran matematika kelas V SDN 1 Metro Timur.

2. Untuk mengetahui adanya perbedaan yang signifikan pada penerapan model quantum teaching terhadap kemampuan berpikir kritis peserta didik pada pembelajaran matematika kelas V SDN 1 Metro Timur.

\section{METODE}

\section{Jenis Penelitian}

Jenis penelitian yang dilakukan adalah penelitian eksperimen. Secara sederhana penelitian eksperimen diartikan sebagai penelitian yang mencari pengaruh dari suatu perlakuan yang diberikan. Hal tersebut sejalan dengan pendapat Sugiyono (2016: 107) bahwa metode penelitian eksperimen dapat diartikan sebagai metode penelitian yang digunakan untuk mencari pengaruh perlakuan tertentu terhadap yang lain dalam kondisi yang terkendalikan.

\section{Tempat Penelitian dan Waktu}

Penelitian ini dilaksanakan di SDN 1 Metro Timur yang beralamat di Jalan Ahmad Yani No.8, Iringmulyo, Kecamatan Metro Timur, Kota Metro. Penelitian 
ini dilaksanakan pada semester genap tahun pelajaran 2019/2020 dimulai dari bulan Februari 2020.

\section{Teknik Pengumpulan Data}

Pengumpulan data merupakan langkah awal yang harus dilakukan dari penelitian karena hakikatnya penelitian merupakan pengumpulan data yang sesungguhnya secara objektif. Teknik pengumpulan data yang digunakan peneliti untuk mengumpulkan keseluruhan data yang berkaitan dengan penelitian ini ada beberapa teknik yang terdiri dari teknis tes dan teknik nontes.

\section{Instrumen Penelitian}

Penelitian ini menggunakan bentuk instrumen tes dan nontes. Instrumen tes yang diberikan berupa soal uraian dengan jumlah soal sebanyak 20 soal berdasarkan kompetensi dasar dan indikator kemampuan berpikir kritis. Tes diberikan kepada kedua kelas yaitu kelompok kontrol dan kelompok eksperimen yaitu pretest dan posttest. Instrumen nontes pada penelitian ini berupa lembar penilaian keterlaksaan model quantum teaching, lembar penilai afekti, dan lembar penilaian psikomotor. Instrumen tes yang telah tersusun, kemudian diujicobakan pada kelas yang bukan menjadi subjek penelitian, untuk menjamin bahwa instrumen yang digunakan baik, maka dilakukan uji validitas dan uji reliabilitas. Uji validitas instrumen menggunakan rumus Product Moment. Sedangkan uji reliabilitas menggunakan teknik Alpha Cronbach.

\section{Teknik Analisis Data}

Teknik analisis data untuk pengujian hipotesis pertama yaitu menggunakan uji regresi linear sederhana. Sedangkan untuk hipotesis kedua menggunakan uji t. 
Adapun signifikansi hubungan dilihat dari hasil perhitungan uji-F dengan kaidah: jika $F_{\text {hitung }}>F_{\text {tabel}}$, artinya terdapat pengaruh yang signifikan atau hipotesis pertama diterima. Dan jika $t_{\text {hitung }}>t_{\text {tabel }}$, artinya terdapat perbedaan yang signifikan atau hipotesis kedua diterima.

\section{HASIL DAN PEMBAHASAN}

\section{Hasil Penelitian}

Kegiatan yang dilakukan sebelum memulai pembelajaran di kelompok eksperimen dan kelompok kontrol adalah dengan memberikan pretest terlebih dahulu. Hal tersebut dilakukan untuk mengetahui kemampuan awal yang dimiliki peserta didik sebelum dilaksanakan pembelajaran di masing-masing kelas. Butir soal yang diberikan sebanyak 15 soal dan sudah diuji validitas dan reliabilitasnya. Berikut nilai pretest kemampuan berpikir kritis peserta didik kelompok eksperimen dan kelompok kontrol.

Tabel 2. Distribusi frekuensi nilai pretest kelompok eksperimen dan kelompok kontrol

\begin{tabular}{|c|c|c|c|c|}
\hline \multirow{2}{*}{ No } & \multicolumn{2}{|c|}{ Kelompok Eksperimen } & \multicolumn{2}{|c|}{ Kelompok Kontrol } \\
\hline & Rentang Nilai & Frekuensi $(f)$ & Rentang Nilai & Frekuensi $(f)$ \\
\hline 1 & $50-55$ & 2 & $38-45$ & 1 \\
\hline 2 & $56-61$ & 4 & $46-53$ & 2 \\
\hline 3 & $62-67$ & 5 & $54-61$ & 3 \\
\hline 4 & $68-73$ & 7 & $62-69$ & 7 \\
\hline 5 & $74-79$ & 5 & $70-77$ & 7 \\
\hline 6 & $80-85$ & 3 & $78-85$ & 6 \\
\hline \multicolumn{2}{|c|}{ Jumlah Peserta Didik } & 26 & & 26 \\
\hline \multicolumn{2}{|c|}{ Rata-rata Nilai } & 68,77 & & 70,23 \\
\hline \multicolumn{2}{|c|}{ Standar Deviasi } & 8,86 & & 11,04 \\
\hline \multicolumn{2}{|c|}{ Tidak Tuntas $(<75)$} & 18 & & 14 \\
\hline \multicolumn{2}{|c|}{ Tuntas $(\geq 75)$} & 8 & & 12 \\
\hline \multicolumn{2}{|c|}{ Persentase Ketuntasan } & $30,77 \%$ & & $46,15 \%$ \\
\hline
\end{tabular}

Sumber: Data perhitungan peneliti. 
Berdasarkan tabel 2, dapat diketahui bahwa nilai pretest peserta didik yang tuntas di kelompok eksperimen dengan KKM 75 berjumlah 8 peserta didik dan yang tidak tuntas berjumlah 18 peserta didik dengan persentase ketuntasan 30,77\%. Adapun nilai pretest peserta didik yang tuntas di kelompok kontrol berjumlah 12 peserta didik dan yang tidak tuntas berjumlah 14 peserta didik dengan persentase ketuntasan 46,15\%. Penggolongan nilai pretest pada kelompok eksperimen dan kelompok kontrol dapat dilihat pada diagram berikut.

\section{Gambar 1. Grafik histogram nilai pretest kelompok eksperimen}

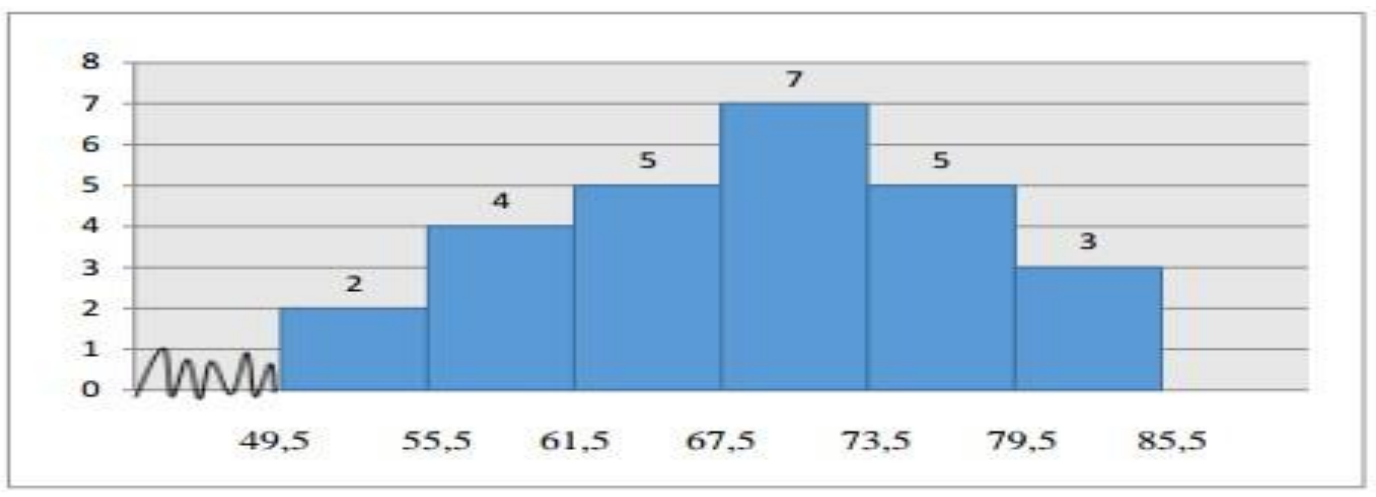

Gambar 2. Grafik histogram nilai pretest kelompok kontrol

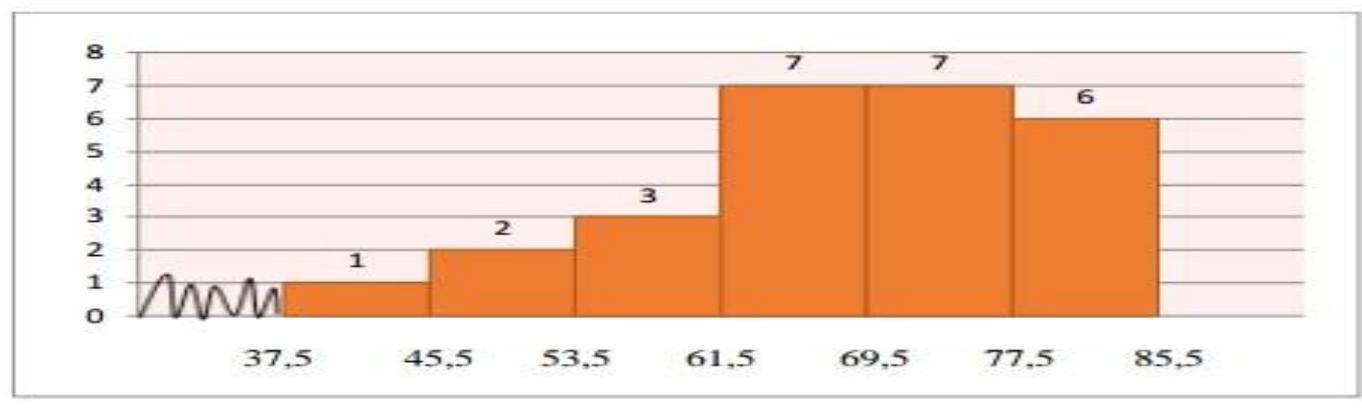

Setelah dilakukan proses pembelajaran dengan menggunakan model quantum teaching di kelas V B sebagai kelompok eksperimen dan pendekatan saintifik di kelas V A sebagai kelompok kontrol, peneliti memberikan posttest pada kelompok eksperimen dan kelompok kontrol dengan menggunakan 
instrumen yang sama. Data hasil posttest kemampuan berpikir kritis peserta didik dapat dilihat pada data berikut.

Tabel 3. Distribusi frekuensi nilai posttest kelompok eksperimen dan kelompok kontrol

\begin{tabular}{|c|c|c|c|c|}
\hline \multirow{2}{*}{ No } & \multicolumn{2}{|c|}{ Kelompok eksperimen } & \multicolumn{2}{|c|}{ Kelompok kontrol } \\
\hline & Rentang Nilai & Frekuensi $(f)$ & Rentang Nilai & Frekuensi $(f)$ \\
\hline 1 & $65-70$ & 2 & $45-53$ & 2 \\
\hline 2 & $71-76$ & 3 & $54-62$ & 3 \\
\hline 3 & $77-82$ & 6 & $63-71$ & 4 \\
\hline 4 & $83-88$ & 8 & $72-80$ & 8 \\
\hline 5 & $89-94$ & 4 & $81-89$ & 6 \\
\hline 6 & $95-100$ & 3 & $90-98$ & 3 \\
\hline \multicolumn{2}{|c|}{ Jumlah Peserta Didik } & 26 & & 26 \\
\hline \multicolumn{2}{|c|}{ Rata-rata Nilai } & 83,85 & & 73,27 \\
\hline \multicolumn{2}{|c|}{ Standar Deviasi } & 8,95 & & 12,32 \\
\hline \multicolumn{2}{|c|}{ Tidak Tuntas $(<75)$} & 4 & & 11 \\
\hline \multicolumn{2}{|c|}{ Tuntas $(\geq 75)$} & 22 & & 15 \\
\hline \multicolumn{2}{|c|}{ Persentase Ketuntasan } & $84,62 \%$ & & $57,69 \%$ \\
\hline
\end{tabular}

Sumber: Data perhitungan peneliti.

Berdasarkan tabel 3, dapat diketahui bahwa nilai posttest peserta didik yang tuntas di kelompok eksperimen dengan KKM 75 berjumlah 22 peserta didik dan yang tidak tuntas berjumlah 4 peserta didik dengan persentase ketuntasan $84,62 \%$ dengan menggunakan model quantum teaching. Adapun nilai posttest peserta didik yang tuntas di kelompok kontrol berjumlah 15 peserta didik dan yang tidak tuntas berjumlah 11 peserta didik dengan persentase ketuntasan $57,69 \%$ dengan menggunakan pendekatan saintifik. Penggolongan nilai posttest pada kelompok eksperimen dan kelompok kontrol dapat dilihat pada diagram berikut.

\section{Gambar 3. Grafik histogram nilai posttest kelompok eksperimen}

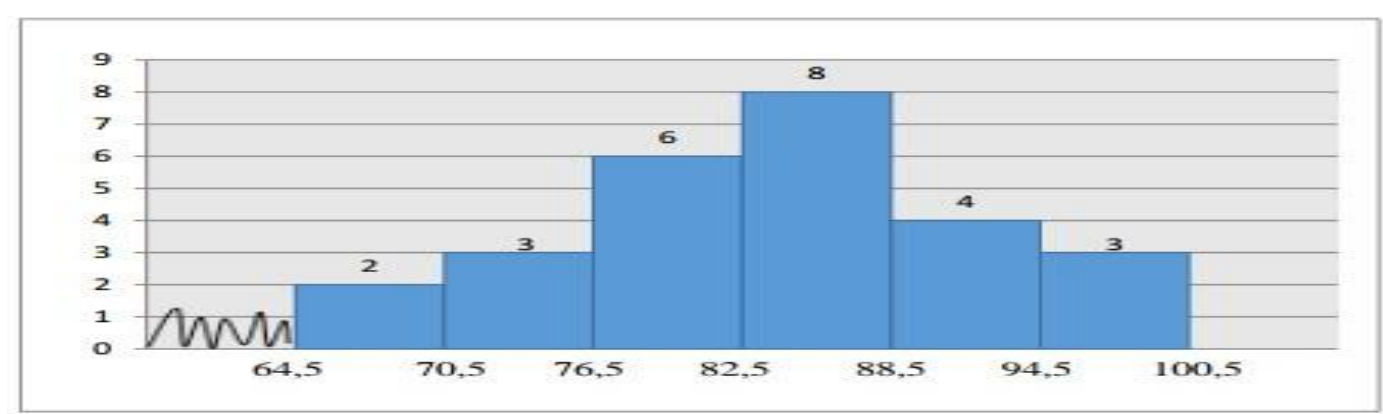


Gambar 4. Grafik histogram nilai posttest kelompok eksperimen

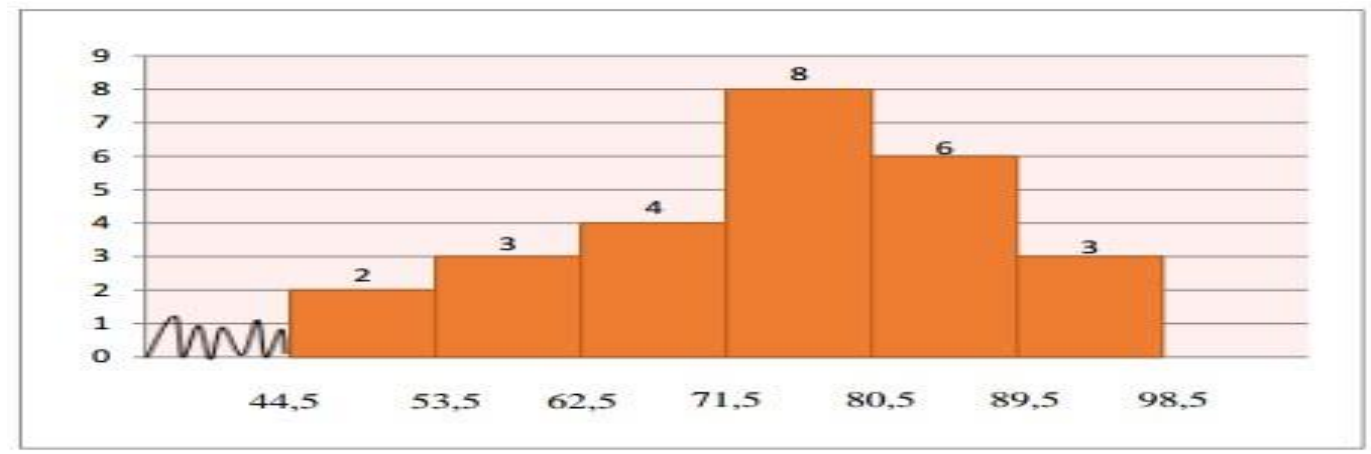

Kelompok eksperimen maupun kelompok kontrol diberikan soal pretest yang butir soalnya sudah diuji validitas dan reliabilitasnya. Soal pretest diberikan bertujuan untuk mengetahui kemampuan awal yang dimiliki peserta didik sebelum diterapkan model pembelajaran pada masing-masing kelas. Berikut nilai rata-rata pretest dan posttest pada masing-masing kelas.

Tabel 4. Rata-rata hasil pretest dan posttest kelompok eksperimen dan kelompok kontrol

\begin{tabular}{|c|c|c|c|c|c|c|c|}
\hline \multirow{2}{*}{ No } & \multirow{2}{*}{$\begin{array}{c}\text { Data } \\
\text { Penelitian }\end{array}$} & \multicolumn{2}{|c|}{ Rata-rata } & \multicolumn{2}{c|}{ Nilai Tertinggi } & \multicolumn{2}{c|}{ Nilai Terendah } \\
\cline { 3 - 8 } & Pretest & Posttest & Pretest & Posttest & Pretest & Posttest \\
\hline 1 & $\begin{array}{l}\text { Kelompok } \\
\text { eksperimen }\end{array}$ & 68,77 & 83,85 & 85 & 100 & 50 & 65 \\
\hline 2 & $\begin{array}{l}\text { Kelompok } \\
\text { kontrol }\end{array}$ & 70,23 & 75,27 & 83 & 98 & 38 & 45 \\
\hline
\end{tabular}

Sumber: Data perhitungan peneliti.

Berdasarkan tabel 4, diketahui bahwa sebelum dilaksanakan pembelajaran, hasil rata-rata pretest kelompok eksperimen sebesar 68,77 dengan nilai tertinggi 85 dan nilai terendah 50, sedangkan hasil posttest kelompok eksperimen menggalami peningkatan setelah diberikan perlakuan model quantum teaching yaitu nilai rata-rata sebesar 83,85 dengan nilai tertinggi sebesar 100 dan nilai terendah sebesar 65 . 
Adapun pada kelompok kontrol hasil rata-rata pretest sebesar 70,23 dengan nilai tertinggi sebesar 83 dan nilai terendah sebesar 38 , setelah diberi perlakuan dengan pendekatan saintifik pada kelompok kontrol mengalami peningkatan namun tidak setinggi kelompok eksperimen yaitu rata-rata 75,27 dengan nilai tertinggi sebesar 98 dan nilai terendah 45. Berikut perbandingan nilai rata-rata pretest dan posttest kelompok eksperimen dan kelompok kontrol.

\section{Gambar 5. Perbandingan nilai rata-rata pretest dan posttest kelompok eksperimen dan kelompok kontrol}

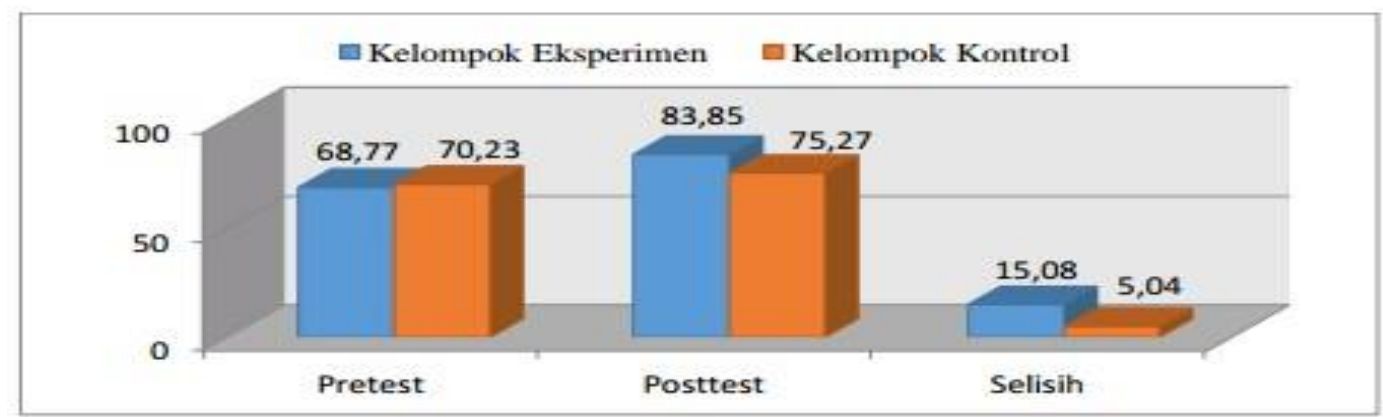

Setelah diketahui nilai kelompok eksperimen dan kelompok kontrol, selanjutnya menghitung peningkatan kemampuan berpikir kritis peserta didik menggunakan rumus $\mathrm{N}$-Gain. Hasil perhitungan $\mathrm{N}$-Gain kemudian digolongkan dalam klasifikasi tinggi, sedang, dan rendah. Berikut tabel klasifikasi nilai $N$-Gain antara kelompok eksperimen dan kelompok kontrol.

Tabel 5. Nilai N-Gain kelompok eksperimen dan kelompok kontrol

\begin{tabular}{|c|c|c|c|c|c|c|}
\hline \multirow{2}{*}{ No } & \multirow{2}{*}{ Kategori } & \multicolumn{2}{|c|}{ Frekuensi } & \multicolumn{2}{c|}{ Rata-rata N-Gain } & Selisih \\
\cline { 3 - 6 } & & $\begin{array}{c}\text { Kelompok } \\
\text { eksperimen }\end{array}$ & $\begin{array}{c}\text { Kelompok } \\
\text { komtrol }\end{array}$ & $\begin{array}{c}\text { Kelompok } \\
\text { Eksperimen }\end{array}$ & $\begin{array}{c}\text { Kelompok } \\
\text { kontrol }\end{array}$ & \\
\hline 1 & Tinggi & 5 & 2 & \multirow{2}{*}{0,48} & 0,20 & 0,28 \\
\hline 3 & Sedang & 16 & 5 & 19 & & \\
\hline
\end{tabular}

Sumber: Data perhitungan peneliti. 
Berdasarkan tabel 5, diketahui bahwa data $N$-Gain peserta didik kelompok eksperimen yang tergolong kategori "Tinggi” 5 orang peserta didik, kategori "Sedang" 16 orang peserta didik, dan kategori "Rendah" 5 orang peserta didik dengan rata-rata $N$-Gain sebesar 0,48 . Adapun kelompok kontrol yang tergolong kategori " Tinggi" sebanyak 2 orang peserta didik, kategori "Sedang" 5 orang peserta didik, dan kategori "Rendah" sebanyak 19 orang peserta didik dengan rata-rata nilai $N$-Gain 0,20 . Kategori perbandingan nilai rata-rata $N$-Gain dapat digambarkan seperti diagram berikut.

\section{Gambar 6. Diagram perbandingan rata-rata $N$-Gain kelompok eksperimen}

\section{dan kelompok kontrol}

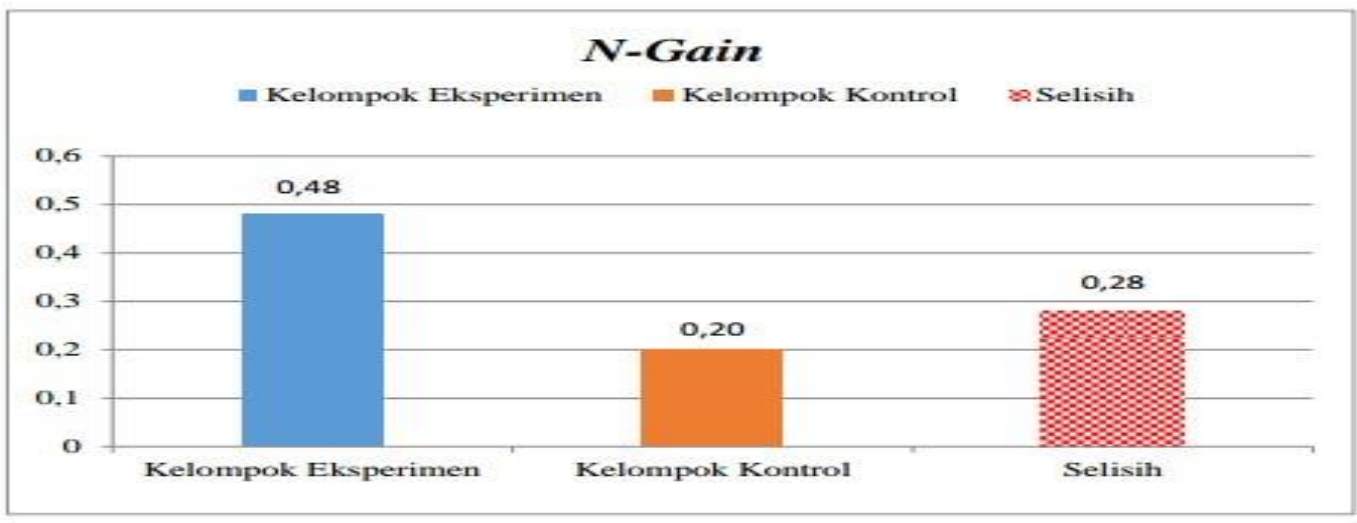

Peneliti melakukan penelitian dan menyampaikan materi dengan menggunakan model quantum teaching pada kelompok eksperimen. Kegiatan awal dimulai dengan memberikan pretest untuk mengetahui kemampuan awal yang dimiliki peserta didik. Kemudian menyampaikan materi pembelajaran volume bangun ruang kubus dan balok. Peneliti memfokuskan pembelajaran pada kemampuan berpikir kritis peserta didik diantaranya yaitu interpretasi, analisis, evaluasi dan keputusan atau membuat kesimpulan. Selanjutnya, di akhir pembelajaran peneliti memberikan posttest kepada peserta didik. 
Berdasarkan hasil posttest, diketahui terjadi perubahan pada kemampuan berpikir kritis peserta didik setelah mendapat perlakuan model quantum teaching. Perubahan tersebut dapat dilihat pada tabel berikut.

Tabel 6. Keterlaksanaan perolehan nilai kemampuan berpikir kritis pada kelompok eksperimen

\begin{tabular}{|c|l|c|c|}
\hline \multirow{2}{*}{ No } & \multirow{2}{*}{ Nilai } & \multicolumn{2}{|c|}{ Frekuensi } \\
\cline { 3 - 4 } & & Pretest & Posttest \\
\hline 1 & Sangat Tinggi $(81,26-100)$ & 2 & 15 \\
\hline 2 & Tinggi $(71,51-81,25)$ & 9 & 9 \\
\hline 3 & Sedang $(62,51-71,50)$ & 9 & 2 \\
\hline 4 & Rendah $(43,76-62,50)$ & 6 & 0 \\
\hline 5 & Sangat Rendah $(\leq 43,75)$ & 0 & 0 \\
\hline \multicolumn{2}{r}{ Jumlah } & 26 & 26 \\
\hline
\end{tabular}

Sumber: Data perhitungan peneliti.

Berdasarkan tabel 6, diketahui bahwa nilai pretest di kelompok eksperimen dengan kategori "Sangat Tinggi" hanya 2 orang peserta didik, kategori "Tinggi" sebanyak 9 orang peserta didik, kategori "Sedang” sebanyak 9 orang peserta didik, dan kategori "Rendah" sebanyak 6 orang peserta didik. Adapun pada hasil posttest kelompok kontrol dengan kategori "Sangat Tinggi" sebanyak 15 orang peserta didik, dan kategori "Tinggi” sebanyak 9 orang peserta didik, dan kategori "Sedang" sebanyak 2 orang peserta didik. Berikut diagram klasifikasi perolehan nilai pada kelompok eksperimen.

Gambar 7. Diagram frekuensi kategori kemampuan berpikir kritis kelompok eksperimen

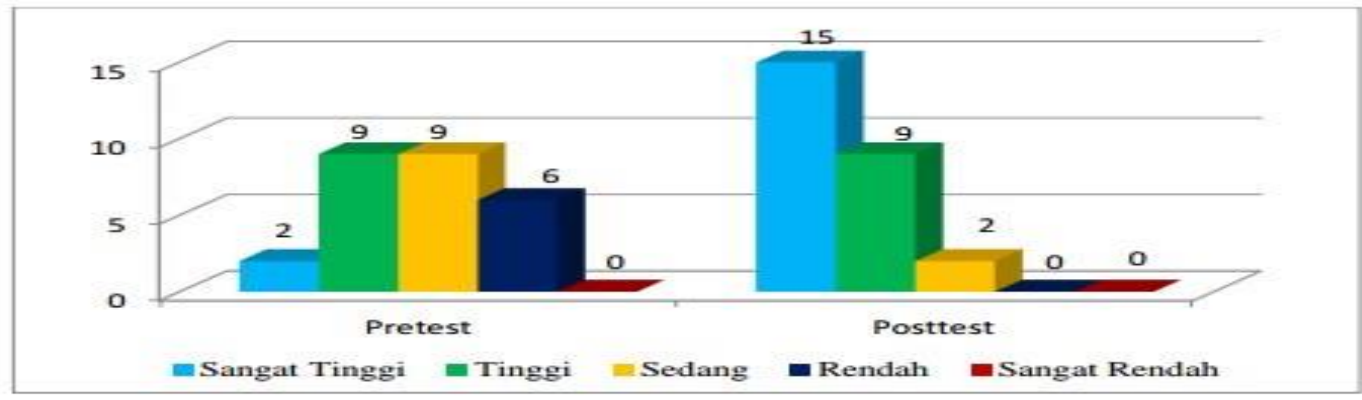


Selain mengambil nilai kognitif, peneliti juga mengambil nilai hasil belajar peserta didik pada ranah afektif dan psikomotor yang diambil melalui lembar observasi yang dilakukan oleh observer. Lembar penilaian afektif berisi instrumen penilaian terhadap partisipasi peserta didik pada kegiatan diskusi kelompok dan sikap peserta didik pada saat pembelajaran berlangsung. Berikut data nilai hasil belajar ranah afektif.

Tabel 7. Data nilai hasil belajar ranah afekti peserta didik kelompok eksperimen dan kelompok kontrol

\begin{tabular}{|c|c|c|c|}
\hline \multirow{2}{*}{ No } & \multirow{2}{*}{ Nilai } & \multicolumn{2}{|c|}{ Frekuensi } \\
\cline { 3 - 4 } & & 2 & Pretest \\
\hline 1 & Sangat Tinggi $(81,26-100)$ & 9 & 15 \\
\hline 2 & Tinggi $(71,51-81,25)$ & 9 & 9 \\
\hline 3 & Sedang $(62,51-71,50)$ & 6 & 2 \\
\hline 4 & Rendah $(43,76-62,50)$ & 0 & 0 \\
\hline 5 & Sangat Rendah $(\leq 43,75)$ & 26 & 26 \\
\hline \multicolumn{2}{r}{ Jumlah } & & \\
\hline
\end{tabular}

Sumber: Data perhitungan peneliti.

Berdasarkan tabel 7, diketahui bahwa nilai afektif di kelompok eksperimen dengan kategori "Sangat Baik" hanya 2 orang peserta didik, kategori "Baik" sebanyak 5 orang peserta didik, kategori "Cukup" sebanyak 17 orang peserta didik, dan kategori "Kurang” berjumlah 2 orang peserta didik.

Adapun pada hasil nilai afektif kelompok kontrol dengan kategori "Sangat Baik" hanya 1 orang peserta didik, dan kategori "Baik" sebanyak 4 orang peserta didik, kategori "Cukup" sebanyak 14 orang peserta didik, dan kategori "Kurang" berjumlah 7 orang peserta didik. Berikut diagram klasifikasi perolehan nilai afektif pada kelompok eksperimen dan kelompok kontrol. 


\section{Gambar 8. Diagram frekuensi hasil nilai afektif kelompok eksperimen dan kelompok kontrol}

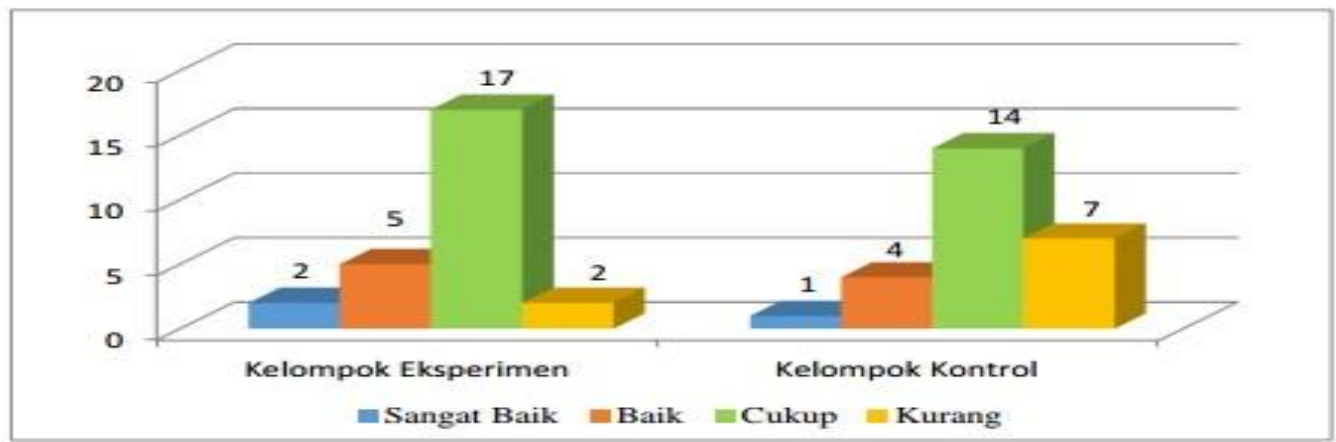

Penilaian psikomotor merupakan penilaian tingkah laku yang tergolong dalam bentuk keterampilan otot atau keterampilan fisik. Penilaian ranah psikomotor diambil melalui lembar observasi yang dilakukan oleh observer. Penilaian ini dilakukan pada kelompok eksperimen dan kelompok kontrol untuk mengetahui kemampuan berpikir kritis peserta didik ketika diterapkan model quantum teaching pada kelompok eksperimen dan pendekatan saintifik pada kelompok kontrol. Berikut data nilai hasil belajar ranah psikomotor.

Tabel 8. Data nilai hasil belajar ranah psikomotor kelompok eksperimen dan kelompok kontrol

\begin{tabular}{|c|l|c|c|}
\hline \multirow{2}{*}{ No } & \multirow{2}{*}{ Nilai } & \multicolumn{2}{|c|}{ Frekuensi } \\
\cline { 3 - 4 } & & $\begin{array}{c}\text { Kelompok } \\
\text { eksperimen }\end{array}$ & $\begin{array}{c}\text { Kelompok } \\
\text { kontrol }\end{array}$ \\
\hline 1 & Sangat Baik (81-100) & 3 & 2 \\
\hline 2 & Baik (66-80) & 8 & 3 \\
\hline 3 & Cukup (51-65) & 12 & 14 \\
\hline 4 & Kurang (46-50) & 3 & 7 \\
\hline 5 & Jumlah & 26 & 26 \\
\hline
\end{tabular}

Sumber: Data perhitungan peneliti.

Berdasarkan tabel 8, diketahui bahwa nilai psikomotor di kelompok eksperimen dengan kategori "Sangat Baik" yaitu 3 orang peserta didik, kategori "Baik" sebanyak 8 orang peserta didik, kategori "Cukup" sebanyak 12 orang 
peserta didik, dan kategori "Kurang" berjumlah 3 orang peserta didik. Adapun pada hasil nilai psikomotor kelompok kontrol dengan kategori "Sangat Baik" hanya 2 orang peserta didik, dan kategori "Baik" sebanyak 3 orang peserta didik, kategori "Cukup" sebanyak 14 orang peserta didik, dan kategori "Kurang" berjumlah 7 orang peserta didik. Berikut diagram klasifikasi perolehan nilai psikomotor pada kedua kelas.

\section{Gambar 9. Diagram frekuensi hasil nilai psikomotor kelompok eksperimen dan kelompok kontrol}

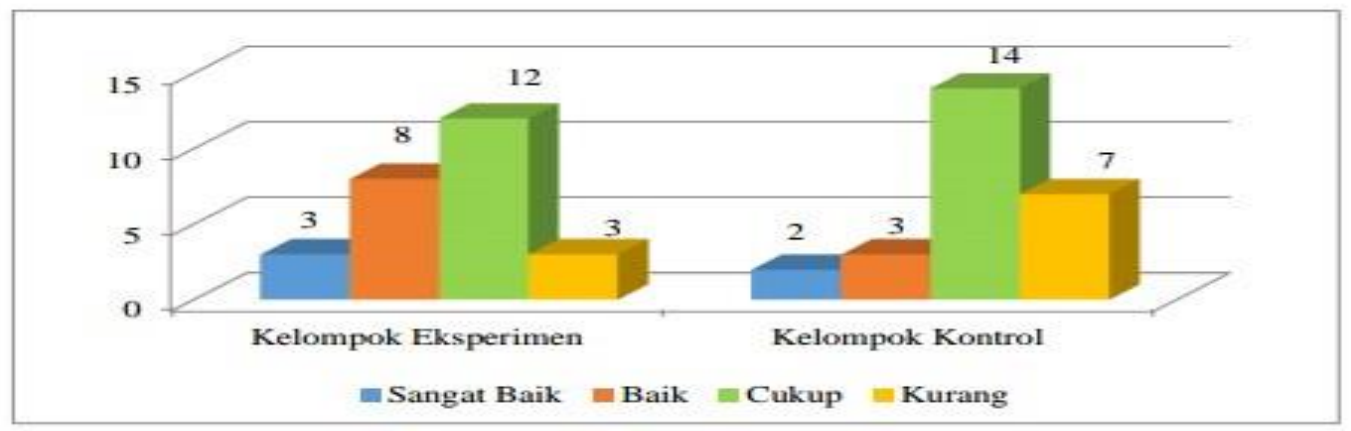

\section{Uji Prasyaratan Analisis Data}

Terdapat dua data yang perlu diuji normalitaskan, yaitu data pretest dan data posttest kelompok eksperimen dan kelompok kontrol. Uji normalitas menggunakan rumus Chi Kuadrat. Interpretasi hasil perhitungan dilakukan dengan membandingkan $\mathrm{x}_{\text {hitung }}^{2}$ dengan $\mathrm{x}_{\text {tabel }}^{2}$ untuk ${ }^{\alpha=0,05}(\mathrm{dk}=\mathrm{k}-1)$. Hasil perhitungan uji normalitas untuk data pretest kelompok eksperimen diperoleh $X_{\text {hitung }}^{2}=1,039 \leq X_{\text {tabel }}^{2}=11,070$ berarti data pretest kelompok eksperimen berdistribusi normal (lampiran 41, halaman 197). Selanjutnya hasil uji normalitas data pretest kelompok kontrol diperoleh ${ }^{X^{2}{ }_{\text {hitung }}}=2,855 \leq X_{\text {tabel }}^{2}=11,070$ berarti data pretest kelompok kontrol berdistribusi normal.

Untuk hasil perhitungan uji normalitas data posttest kelompok eksperimen diperoleh $\quad X_{\text {hitung }}^{2}=1,371 \leq X_{\text {tabel }}^{2}=11,070$ berarti data posttest kelompok 
eksperimen berdistribusi normal. Adapun hasil perhitungan uji normalitas untuk data posttest kelompok kontrol diperoleh ${ }^{X_{\text {hitung }}^{2}}=1,991 \leq X_{\text {tabel }}^{2}=11,070$ berarti data posttest kelompok kontrol berdistribusi normal.

Uji homogenitas dihitung dengan menggunakan rumus uji-F. Kaidah keputusan jika $F_{\text {hitung }}<F_{\text {tabel }}$ maka varians homogen, sedangkan jika $F_{\text {hitung }}>F_{\text {tabel }}$ maka varians tidak homogen. Taraf signifikan yang ditetapkan adalah 0,05. Hasil perhitungan didapat niai ${ }^{F_{\text {hitung }}}$ untuk pretest yaitu ${ }^{F_{\text {hitung }}=1,73<\mathrm{F}_{\text {tabel }}}=1,96$ dan posttest $^{\mathrm{F}_{\text {hitung }}}=1,90<\mathrm{F}_{\text {tabel }}=1,96$. Berdasarkan perbandingan nilai $\mathrm{F}$ tersebut maka dapat disimpulkan bahwa populasi memilik varians yang homogen.

\section{Uji Hipotesis}

1. Uji Regresi Linear Sederhana

Berdasarkan hasil perhitungan diperoleh hasil $\mathrm{F}_{\text {hitung }}=6,06$ dengan $n=26$ untuk taraf kesalahan $5 \%$ atau 0,05 maka didapat $\mathrm{F}_{\text {tabel }}=4,26$. Data tersebut menunjukkan bahwa $F_{\text {hitung }}>F_{\text {tabel }}$ yaitu $6,06>4,26$, maka Ho ditolak artinya diterima yaitu "Terdapat pengaruh yang signifikan pada penerapan model quantum teaching terhadap kemampuan berpikir kritis peserta didik pada pembelajaran matematika kelas V SDN 1 Metro Timur".

\section{Uji t}

Berdasarkan analisis diketahui nilai $\mathrm{dk}=(26-1)=25$ dengan taraf signifikansi $5 \%$, maka didapat $\mathrm{t}_{\text {tabel }}=2,060$, sedangkan hasil perhitungan nilai $t_{\text {hitung }}=2,873$ sehingga $t_{\text {hitung }}=2,873>t_{\text {tabel }}=2,060$ yang artinya $H_{\mathrm{a}}$ diterima yaitu “Terdapat perbedaan yang signifikan pada penerapan model quantum teaching terhadap kemampuan berpikir kritis peserta didik pada pembelajaran matematika kelas V SDN 1 Metro Timur". 


\section{Pembahasan}

Berdasarkan analisis data setelah penelitian diketahui bahwa rata-rata pretest kemampuan berpikir kritis pada kelompok eksperimen adalah 68,77 sedangkan rata-rata posttest kelompok eksperimen adalah 83,85 terdapat peningkatan sebesar 15,05 . Adapun rata-rata pretest kemampuan berpikir kritis pada kelompok kontrol adalah 70,23 sedangkan rata-rata posttest kemampuan berpikir kritis pada kelompok kontrol adalah 75,27, terdapat peningkatan sebesar 5,04 .

Nilai $\mathrm{N}$-Gain atau peningkatan kemampuan berpikir kritis antara nilai pretest dan posttest menunjukkan rata-rata $N$-Gain kelompok eksperimen yaitu 0,48 dengan kategori "Sedang" dan kelompok kontrol yaitu 0,20 dengan kategori "Rendah". Selisih $N$-Gain kedua kelas yaitu 0,28. Hal ini menunjukkan bahwa peningkatan kemampuan berpikir kritis di kelompok eksperimen lebih tinggi dibandingkan dengan kelompok kontrol. Proses pembelajaran dengan model quantum teaching pada kelompok eksperimen mampu berperan aktif dan meningkatkan kemampuan berpikir kritis peserta didik diantaranya yaitu interpretasi, analisis, evaluasi dan membuat kesimpulan. Berdasarkan hal tersebut telah terjadi perubahan dalam belajar pada diri peserta didik ke arah yang lebih baik.

Hasil pengujian nilai posttest kemampuan berpikir kritis menunjukkan bahwa kedua kelas tersebut berdistribusi normal dan varians homogen, rata-rata kemampuan berpikir kritis kelompok eksperimen lebih tinggi dibandingkan dengan rata-rata kemampuan berpikir kritis kelompok kontrol. Artinya terdapat perbedaan kemampuan berpikir kritis kelas yang diberi perlakuan model quantum 
teaching dengan kelas yang tidak diberi perlakuan model quantum teaching. Adapun hasil uji hipotesis dengan rumus regresi sederhana diketahui bahwa $F_{h i t u n g}$ $>\mathrm{F}_{\text {tabel }}$ atau 6,06 > 4,26 sedangkan hasil uji hipotesis menggunakan rumus $t$-test adalah $t_{\text {hitung }}=2,873>t_{\text {tabel }}=2,060$.

Hasil dari penelitian dan pengamatan tersebut sesuai dengan pendapat Poter (2014: 47) bahwa model pembelajaran quantum teaching memiliki kelebihan yaitu memberikan kebebasan belajar, menjadikan peserta didik lebih aktif dan berani mengungkapkan pendapat atau ide, pemahan peserta didik terhadap materi cukup tinggi, dan menciptakan keriangan dan ketakjuban dalam belajar.

\section{PENUTUP}

\section{Kesimpulan}

Berdasarkan hasil analisis data dan pembahasan penelitian, dapat disimpulkan bahwa terdapat pengaruh yang signifikan pada penggunaan model quantum teaching terhadap kemampuan berpikir kritis peserta didik pada pembelajaran matematika kelas V SDN 1 Metro Timur. Peningkatan kemampuan berpikir kritis peserta didik dengan model quantum teaching sebesar 0,48 dengan kategori "Sedang" ditunjukkan dengan nilai uji hipotesis posttest kelompok eksperimen dan kelompok kontrol yaitu $t_{\text {hitung }}>t_{\text {tabel }}$ yaitu 2,873 $>2,060$ serta terdapat nilai $\mathrm{F}_{\text {hitung }}>\mathrm{F}_{\text {tabel }}$ yaitu $6,06>4,26\left(\right.$ dengan $\left.{ }^{\alpha=0,05}\right)$. Maka peneliti menyimpulkan bahwa (1) Terdapat pengaruh yang signifikan pada penerapan model quantum teaching terhadap kemampuan berpikir kritis peserta didik pada pembelajaran matematika kelas V SDN 1 Metro Timur (2) Terdapat perbedaan yang signifikan pada penerapan model quantum teaching terhadap kemampuan 
berpikir kritis peserta didik pada pembelajaran matematika kelas V SDN 1 Metro Timur.

\section{DAFTAR RUJUKAN}

Azizah dkk. 2018. Analisis Kemampuan Berpikir Kritis Siswa Sekolah Dasar pada Pembelajaran Matematika Kurikulum 2013. Jurnal Penelitian Pendidikan. Vol 35 (1): 61-70.

Poter, dkk. 2014. Quantun Teaching: Mempraktikkan Quantum Learning di Ruangruang Kelas. Kaifa, Bandung.

Rosyida, dkk. 2016. Memberdayakan Keterampilan Berpikir Kritis dengan Model Pembelajaran Remap TmPS (Reading Concepy Map Timed Pair Share). 13(1): 209-214.

Shanti, dkk. 2017. Meningkatkan Kemampuan Berpikir Kritis melalui Problem Posing. LITERASI. 8 (1): 49-59.

Sugiyono. 2016. Metode Penelitian Kuantitatif, Kualitatif, dan R\&D. Alfabeta, Bandung.

Supramono, Agus. 2016. Pengaruh Model Pembelajaran Quantum Teaching terhadap Hasil Belajar IPA Siswa Kelas III SD YPS Lawewu Kecamatan Nuha Kabupaten Luwu Timur. Jurnal Nalar Pendidikan. 4 (2): 78-86.

Wena, Made. 2014. Strategi Pembelajaran Inovasi Konteporer. Bumi Aksara, Jakarta. 